\title{
Structural Studies of Polyesters. VII. Molecular and Crystal Structures of Racemic Poly $(\beta$-ethyl- $\beta$-propiolactone)
}

\author{
Mitsuru Yokouchi, Yozo Chatani, Hiroyuki Tadokoro, and Hisaya Tani \\ Department of Polymer Science, Faculty of Science, \\ Osaka University, Toyonaka, Osaka 560, Japan.
}

(Received December 11, 1973)

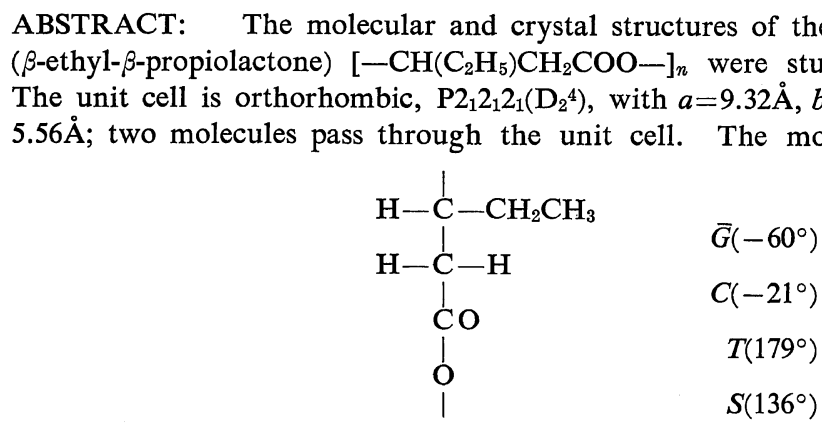

shown by the Fischer projection for the case of the rectus polymer, giving a left-handed (2/1) helix: the $\mathrm{O}-\mathrm{C}$ bond is nearly skew, $136^{\circ}$, and the $\mathrm{C}-\mathrm{C}(\mathrm{O})$ bond is far from the gauche form, $-21^{\circ}$. The internal rotation angle about the sequence $\mathrm{O}-\mathrm{CH}-\mathrm{CH}_{2}-\mathrm{CH}_{3}$ is $64^{\circ}$. From the results of the X-ray analysis, it may be concluded that (1) the crystalline polymer prepared from the racemic monomer, $\beta$-ethyl- $\beta$-propiolactone, is isotactic and (2) the bulk sample of this racemic polymer consists of two kinds of crystallites, one composed only of left-handed helices of rectus polymer chains, the other only of right-handed helices of sinister polymer chains.

KEY WORDS Structure of Poly( $\beta$-ethyl- $\beta$-propiolactone) / X-ray Diffraction / Energy Calculation / Constrained Least-Squares Method / Isotactic Polymer /

In a previous paper, ${ }^{1}$ the crystal structure of poly $\left(\beta\right.$-hydroxybutyrate) $\left[-\mathrm{CH}\left(\mathrm{CH}_{3}\right) \mathrm{CH}_{2} \mathrm{COO}-\right]_{n}$ has been reported as an extension of the structural studies of aliphatic polyesters. In the present paper, the crystal structure of racemic $\operatorname{poly}(\beta-$ ethyl- $\beta$-propiolactone) $\left[-\mathrm{CH}\left(\mathrm{C}_{2} \mathrm{H}_{5}\right) \mathrm{CH}_{2} \mathrm{COO}-\right]_{n}$ is reported. On the basis of X-ray analysis, several models of molecular conformation were selected by utilizing the calculations of the intramolecular interaction energies.

\section{EXPERIMENTAL}

\section{Sample}

Monomer, DL- $\beta$-ethyl- $\beta$-propiolactone, was obtained by reacting propionaldehyde with ketene; the preparative separation was carried out by using a Silicone DC-500 (Dow Chemical Co.) column.
Racemic polymer was prepared by polymerizing DL- $\beta$-ethyl- $\beta$-propiolactone with $\mathrm{AlEt}_{3}-\mathrm{H}_{2} \mathrm{O}-$ epichlorohydrine catalyst. The melting point of the crystalline polymer is $105-108^{\circ} \mathrm{C}^{2}$ The samples for X-ray measurements were prepared by quick drawing of the molten sample during the cooling process to room temperature, followed by further elongation giving necking, and heattreatment at $92^{\circ} \mathrm{C}$ under tension in vacuo for one day.

\section{X-Ray Measurements}

Throughout the present study, X-ray photographs were taken by using nickel-filtered $\mathrm{Cu}-\mathrm{K} \alpha$ radiation. An X-ray photograph of racemic $\operatorname{poly}(\beta$-ethyl- $\beta$-propiolactone) taken with a cylindrical camera is given in Figure 1 . The meridional reflection data were taken from the 


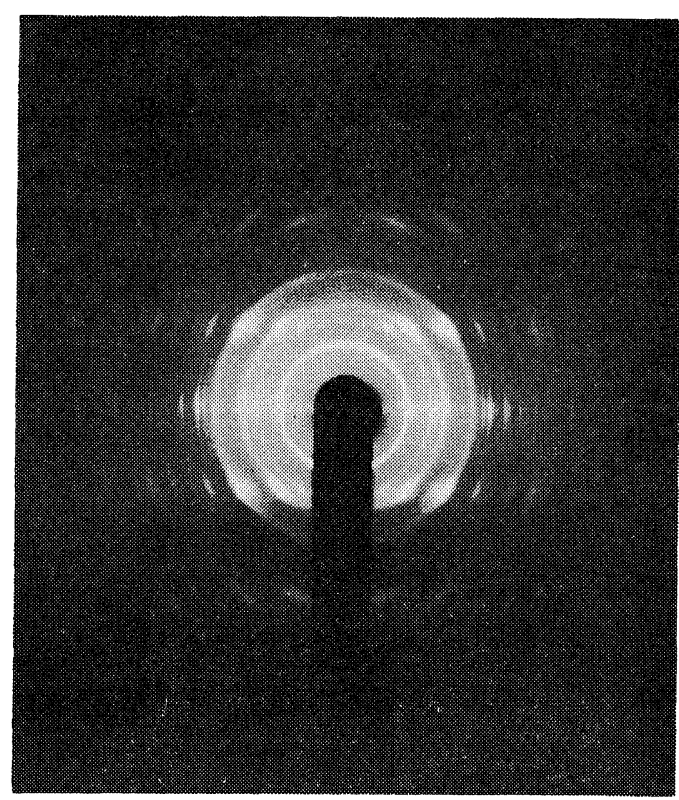

Figure 1. X-ray fiber photograph of racemic poly( $\beta$-ethyl- $\beta$-propiolactone).

photograph using a Weissenberg camera, where the sample was oscillated about an axis normal to the fiber axis. From the photograph in Figure 1 , sixty-one independent reflections were observed. The camera radius was corrected with the spacings of the reflections of aluminum powder. The reflection intensities of the fiber diagram obtained by the multiple-film method were measured by visual comparison with a standard intensity scale. The corrections using Lorentz-polarization factors and the obliquity effect in the fiber diagram were made.

\section{ANALYSIS AND RESULTS}

\section{Unit Cell and Space Group}

The reflections observed on the photograph could be indexed by an orthorhombic cell: $a=$ $9.32 \AA, b=10.02 \AA$, and $c$ (fiber identity period $)=$ $5.56 \AA$. Assuming four monomeric units in the cell, the calculated density is $1.28 \mathrm{~g} / \mathrm{ml}$, and this value is in agreement with the observed density measured by the flotation method, $1.20 \mathrm{~g} / \mathrm{ml}$. The space group is $\mathrm{P} 22_{1} 2_{1} 2_{1}\left(\mathrm{D}_{2}{ }^{4}\right)$ from the following systematic absences: $h 00$ when $h$ is odd, $0 k 0$ when $k$ is odd, and $00 l$ when $l$ is odd. This space group is the same as that of poly $(\beta$-hydroxybutyrate). ${ }^{1}$ It was assumed from these experi- mental data that this polymer molecule has a two-fold helical symmetry relating two monomeric units, and that two molecules pass through the unit cell.

\section{Molecular Models}

According to the conformational energy calculations reported so far, the conformations of polymers predicted from the calculated energies were in agreement with the reported crystallographic results. ${ }^{3}$ Polypivalolactone $\left[-\mathrm{CH}_{2} \mathrm{C}\left(\mathrm{CH}_{3}\right)_{2}\right.$ $\mathrm{COO}-]_{n},{ }^{4} \operatorname{poly}(\beta$-hydroxybutyrate $)$, and $\operatorname{poly}(\beta$ ethyl- $\beta$-propiolactone) have the same main chain chemical structures, but have different kinds and positions of substituent groups. From the results of the energy calculations of polypivalolactone and $\operatorname{poly}(\beta$-hydroxybutyrate $),{ }^{5}$ the parameters for the energy calculation of the isolated polyester chain seemed to be reliable. Therefore, we tried an application of the energy calculation to the structure analysis of poly ( $\beta$-ethyl- $\beta$-propiolactone).

The conformational energies were calculated for all the possible rectus polymer chain models with two-fold helical symmetry, by fixing the fiber identity period of $5.56 \AA$. The energies were computed by taking into account the internal rotation barriers, the nonbonded interactions, and the dipole-dipole interactions, where the bond lengths and the bond angles were fixed. The parameters for the energy calculation in the present paper were the same as those used in ref 5 , and the following bond lengths and bond angles were assumed: $\mathrm{C}-\mathrm{C}=1.54 \AA, \mathrm{C}-\mathrm{H}=$ $1.09 \AA, \mathrm{C}-\mathrm{O}=1.43 \AA, \mathrm{C}-\mathrm{C}(\mathrm{O})=1.52 \AA, \mathrm{C}(\mathrm{O})-$ $\mathrm{O}=1.36 \AA, \quad \mathrm{C}(\mathrm{O})=\mathrm{O}=1.23 \AA, \quad \angle \mathrm{C}-\mathrm{C}(\mathrm{O})-\mathrm{O}=$ $115^{\circ}, \quad \angle \mathrm{C}-\mathrm{C}(\mathrm{O})=\mathrm{O}=\angle \mathrm{O}=\mathrm{C}(\mathrm{O})-\mathrm{O}=122.5^{\circ}$, and $\angle \mathrm{C}(\mathrm{O})-\mathrm{O}-\mathrm{C}=112^{\circ}$, while all the other bond angles were regular tetrahedral $[\mathrm{C}(\mathbf{O})$ is the carbon atom of the carbonyl group]. The numbering of the atoms and the internal rotation angles are as follows:

$$
\begin{gathered}
\mathrm{C}_{\mathrm{IV}}-\mathrm{C}_{\mathrm{V}} \mathrm{O}_{\mathrm{II}} \\
-\mathrm{O}_{\mathrm{I}}(-1)-\tau_{\mathrm{S}} \mathrm{C}_{\mathrm{I}}-\mathrm{C}_{\mathrm{II}}-\mathrm{C}_{\mathrm{III}}-\mathrm{O}_{\mathrm{I}}-\mathrm{C}_{\mathrm{I}}(+1)- \\
\tau_{1} \tau_{2} \tau_{3} \tau_{4}
\end{gathered}
$$

The internal rotation angle about the sequence $\mathrm{O}_{\mathrm{I}}(-1)-\mathrm{C}_{\mathrm{I}}-\mathrm{C}_{\mathrm{IV}}-\mathrm{C}_{\mathrm{V}}$ is expressed as $\tau_{\mathrm{s}}$. From the results of the structure analyses of polyesters, ${ }^{1}$ the internal rotation angle $\tau_{3}$ was reasonably fixed at $180^{\circ}$. By fixing $\tau_{3}$ at $180^{\circ}$ and 
(b)

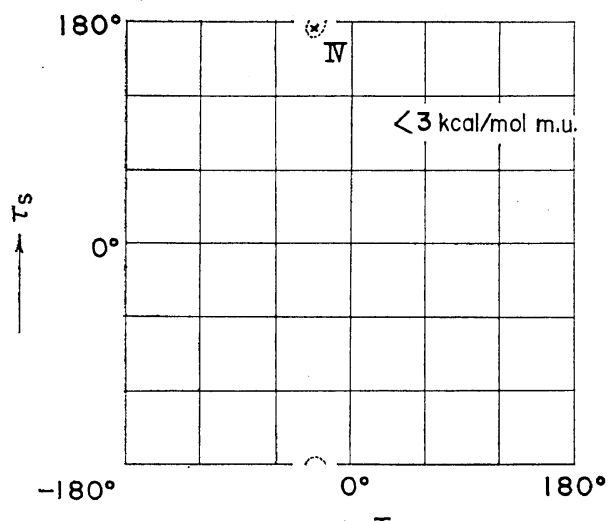

(a)

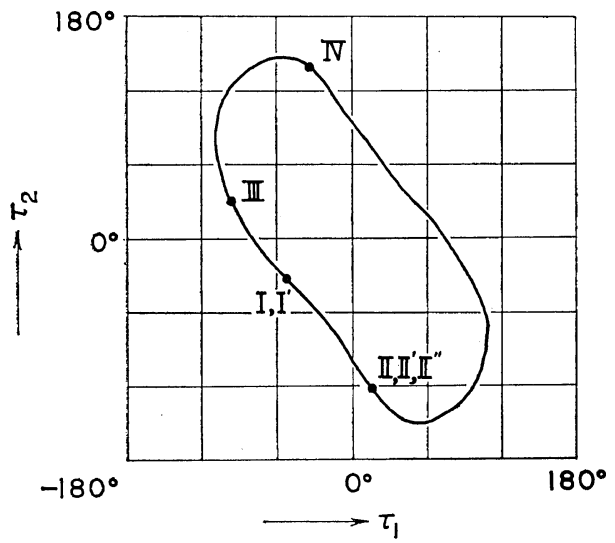

(c)

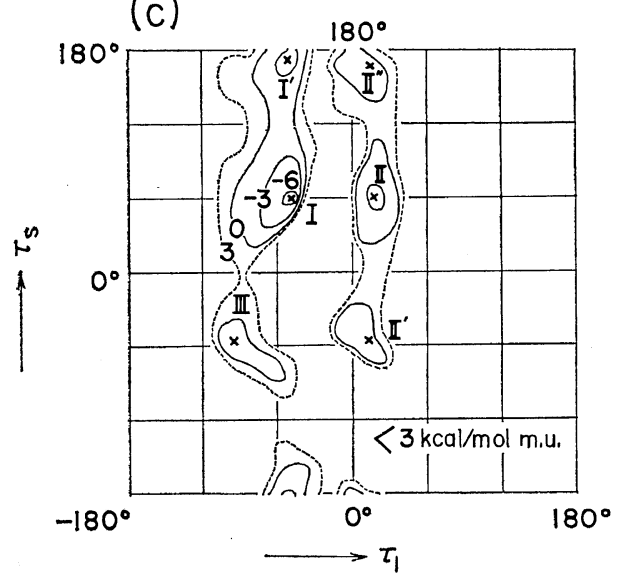

Figure 2. (a) Three-dimensional closed curve showing the relationship between $\tau_{1}, \tau_{2}$, and $\tau_{4}$ for a possible conformation of the main chain of poly $(\beta-$ ethyl- $\beta$-propiolactone); (b) the energy contour map of the rectus polymer chain on the $\tau_{1}-\tau_{\mathrm{s}}$ plane for the upper part of the closed curve shown in (a); (c) the energy contour map for the lower part of the closed curve.
Table I. Energetically stable molecular models

\begin{tabular}{crrrrrrl}
\hline Model & $\tau_{1},{ }^{\circ}$ & $\tau_{2},{ }^{\circ} \tau_{3},{ }^{\circ} \tau_{4},{ }^{\circ} \tau_{\mathrm{s}},^{\circ}$ & $E^{\mathrm{a}}$ & $R, \%$ \\
\hline I & -51 & -34 & 180 & 138 & 61 & -6.0 & 26.7 \\
I' $^{\prime}$ & -51 & -34 & 180 & 138 & 171 & -3.8 & $40.5^{\mathrm{b}}$ \\
II & 15 & -122 & 180 & 71 & 62 & -3.9 & 42.8 \\
II' $^{\prime}$ & 15 & -122 & 180 & 71 & -54 & -2.6 & $43.4^{\mathrm{b}}$ \\
II' $^{\prime \prime}$ & 15 & -122 & 180 & 71 & 166 & -2.2 & $49.2^{\mathrm{b}}$ \\
III & -94 & 31 & 180 & 113 & 54 & -0.8 & 34.8 \\
IV & -31 & 141 & 180 & -55 & 175 & 2.3 & 36.8 \\
\hline
\end{tabular}

a $\mathrm{kcal} / \mathrm{mol} \mathrm{m} . \mathrm{u}$.

b Only the equatorial reflections.

varying $\tau_{1}$ and $\tau_{2}$ from $-180^{\circ}$ to $180^{\circ}$, the values of $\tau_{4}$ for all possible molecular models were obtained, which satisfy the two-fold helical symmetry and the fiber identity period of $5.56 \AA$. The possible sets of the internal rotation angles are on one closed curve in a cube defined by the three-dimensional Cartesian coordinates, $\tau_{1}$, $\tau_{2}$, and $\tau_{4}$, each covering from $-180^{\circ}$ to $180^{\circ}$. In Figure $2 \mathrm{a}$, the projection of the closed curve on the $\tau_{1}-\tau_{2}$ plane is shown. Since the rotation of the side group (ethyl group) is independent of the conformation of the main chain, there is another degree of freedom: $\tau_{\mathrm{s}}$ can vary from $-180^{\circ}$ to $180^{\circ}$ on the closed curve. The energy contour maps in the $\tau_{1}-\tau_{\mathrm{s}}$ planes of the upper part and the lower part of the closed curve are shown in Figures $2 \mathrm{~b}$ and $\mathrm{c}$, respectively, where the methyl group was assumed to be in the staggered form. From these calculations, seven potential minima were found. The internal rotation angles and the conformational energies, $E$, are listed in Table I. A prime and double prime indicate a difference in the conformation of the side chain. In Figure 3, models I, II, III, and IV of the seven rectus polymer models are shown. Thus, we succeeded in selecting seven models from an infinitely large number of molecular models, but we could not conclude which was the most acceptable one from the results of the energy calculation alone.

\section{Structure Factor Calculations}

The crystal structure factors were calculated for these seven molecular models. There remain two variable parameters for the space group $\mathrm{P} 22_{1} 2_{1}\left(\mathrm{D}_{2}{ }^{4}\right)$, i.e., the azimuthal angle about the helix axis and the translation along the $c$ axis (fiber axis). At first, the azimuthal angle was 

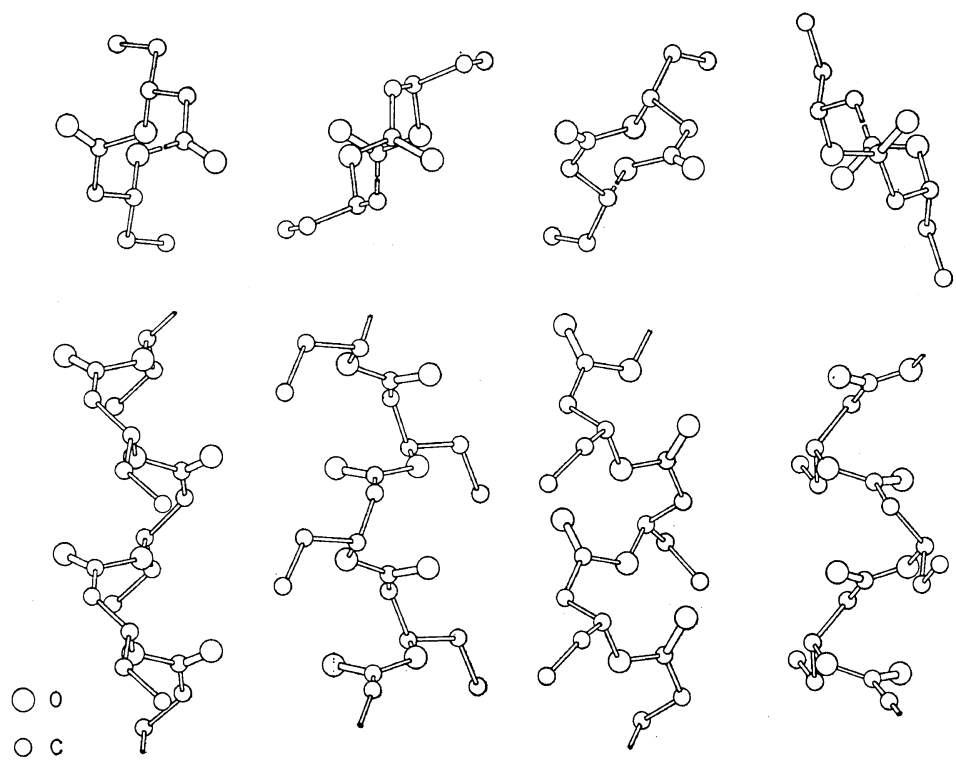

model I

model II

model II

model IV

Figure 3. Four energetically stable molecular models for the rectus polymer.

determined for each molecular model so that close agreement between the observed and calculated structure factors for the equatorial reflections could be obtained. Fixing the azimuthal angle thus obtained for each molecular model, the translational parameter was determined by the use of the 1st- and 2nd-layer reflection data. The values of the discrepancy factor

$$
R=\sum\left|\left(I_{0}\right)^{1 / 2}-\left(I_{\mathrm{C}}\right)^{1 / 2}\right| / \Sigma\left(I_{\mathrm{O}}\right)^{1 / 2}
$$

of the molecular models for all the observed reflections are listed in Table I. From the values of the $R$ factor and the conformational energy, model I was considered to be the most probable. Then, the atomic coordinates and the thermal coefficients in the crystal were refined by the

Table II. Atomic coordinates and thermal coefficients

\begin{tabular}{lcrcc}
\hline & $x$ & $y$ & $z$ & $B, \AA^{2}$ \\
\hline $\mathrm{C}_{\mathrm{I}}$ & 0.398 & -0.049 & 0.575 & 4.2 \\
$\mathrm{C}_{\text {II }}$ & 0.358 & -0.161 & 0.745 & 6.7 \\
$\mathrm{C}_{\text {III }}$ & 0.240 & -0.121 & 0.900 & 3.8 \\
$\mathrm{C}_{\text {IV }}$ & 0.527 & -0.092 & 0.416 & 7.8 \\
$\mathrm{C}_{\mathrm{V}}$ & 0.578 & 0.026 & 0.268 & 6.3 \\
$\mathrm{O}_{\mathrm{I}}$ & 0.282 & -0.013 & 0.426 & 5.0 \\
$\mathrm{O}_{\text {II }}$ & 0.160 & -0.201 & 1.004 & 5.2 \\
\hline
\end{tabular}

Polymer J., Vol. 6, No. 3, 1974 constrained least-squares method $^{6,7}$ by using model I as a starting model. The discrepancy factor $R$ was reduced to $19.5 \%$. Table II lists the atomic coordinates and the thermal coefficients. The crystal structure of the rectus polymer chains is shown in Figure 4 with its symmetry elements. The comparison between the observed and calculated intensities is given in Table III. For all the computations, the NEAC-2200 model700 electronic computer in this University was used.

\section{DISCUSSION}

It was found from the $X$-ray analysis of racemic poly( $\beta$-ethyl- $\beta$-propiolactone) that each crystallite is composed of only rectus polymer chains or only sinister polymer chains, of which one is the mirror image of the other. Therefore, in the bulk sample of this racemic polymer, two kinds of crystallites compensate for the optical activity of each other. The same kind of optical compensation has been already reported for the cases of poly(propylene sulfide) $)^{8}$ and $\operatorname{poly}(\beta$ hydroxybutyrate). ${ }^{1}$ This also implies that the synthesized crystalline poly( $\beta$-ethyl- $\beta$-propiolactone) prepared from the racemic monomer is 
M. Yokouchi, Y. Chatani, H. Tadokoro, and H. TANI

Table III. Comparison of observed and calculated structure factors for racemic poly( $\beta$-ethyl- $\beta$-propiolactone)

\begin{tabular}{|c|c|c|c|c|c|c|c|c|c|}
\hline$h$ & $k$ & $l$ & $\left(I_{0}\right)^{1 / 2 \mathrm{a}}$ & $\left(I_{\mathrm{c}}\right)^{1 / 2 \mathrm{~b}}$ & $h$ & $k$ & $l$ & $\left(I_{\circ}\right)^{1 / 2 \mathrm{a}}$ & $\left(I_{\mathrm{c}}\right)^{1 / 2 \mathrm{~b}}$ \\
\hline 1 & 1 & 0 & 121.6 & 114.9 & 4 & 8 & $0\}$ & \multirow{3}{*}{ - } & \multirow{3}{*}{18.5} \\
\hline 0 & 2 & 0 & 68.3 & 60.6 & 8 & 3 & $0\}$ & & \\
\hline 2 & 0 & 0 & 29.6 & 29.7 & 8 & 4 & 0 & & \\
\hline 1 & 2 & 0 & 66.7 & 47.1 & 6 & 7 & 0 & \multirow{3}{*}{18.6} & \multirow[t]{3}{*}{20.7} \\
\hline 2 & 1 & 0 & - & 6.6 & 3 & 9 & $0\}$ & & \\
\hline 2 & 2 & 0 & 19.7 & 8.8 & $\begin{array}{l}7 \\
0\end{array}$ & 6 & 0) & & \\
\hline 1 & 3 & 0 & 33.6 & 32.3 & 0 & $\begin{array}{l}1 \\
0\end{array}$ & $\left.\begin{array}{l}1 \\
1\end{array}\right\}$ & 26.1 & 28.3 \\
\hline 3 & 1 & 0 & 54.7 & 57.8 & $\begin{array}{l}1 \\
1\end{array}$ & 1 & 1 & 72.6 & 84.7 \\
\hline 2 & 3 & 0 & 38.4 & 42.9 & 0 & 2 & 1 & 37.8 & 36.3 \\
\hline 3 & 2 & 0 & 17.7 & 18.7 & 2 & 0 & 1 & 39.3 & 52.6 \\
\hline 0 & 4 & 0 & 28.3 & 16.9 & 1 & 2 & 1) & \multirow{2}{*}{79.3} & \multirow{2}{*}{86.1} \\
\hline 1 & 4 & 0 & 20.8 & 21.9 & $\begin{array}{l}1 \\
2\end{array}$ & $\begin{array}{l}2 \\
1\end{array}$ & $1\}$ & & \\
\hline 4 & 0 & 0 & - & 4.6 & 2 & 2 & $1)$ & \multirow{2}{*}{40.4} & \multirow[b]{2}{*}{46.7} \\
\hline 3 & 3 & $0\}$ & 30.1 & 326 & 0 & 3 & $1\}$ & & \\
\hline 4 & 1 & $0\}$ & 30.1 & 32.6 & 1 & 3 & $1)$ & \multirow[b]{2}{*}{23.6} & \multirow{2}{*}{23.5} \\
\hline 2 & 4 & 0 & 19.6 & 12.8 & 3 & 0 & $1\}$ & & \\
\hline 4 & 2 & 0 & 14.1 & 25.4 & 3 & 1 & 1 & 29.0 & 29.4 \\
\hline 1 & 5 & 0 & 388 & 430 & 2 & 3 & 1 & 37.0 & 22.5 \\
\hline 3 & 4 & $0\}$ & 38.8 & 43.0 & 3 & 2 & 1 & 37.7 & 18.8 \\
\hline 4 & 3 & 0 & - & 9.1 & 0 & 4 & 1 . & \multirow{2}{*}{45.2} & \multirow{2}{*}{44.7} \\
\hline $\begin{array}{l}2 \\
5\end{array}$ & $\begin{array}{l}5 \\
1\end{array}$ & $\left.\begin{array}{l}0 \\
0\end{array}\right\}$ & 13.8 & 15.5 & 1 & 4 & 1) & & \\
\hline 5 & 2 & 0 & 14.2 & 5.8 & $\begin{array}{l}4 \\
3\end{array}$ & $\begin{array}{l}0 \\
3\end{array}$ & $\begin{array}{l}1 \\
1\end{array}$ & \multirow[t]{2}{*}{47.3} & \multirow[t]{2}{*}{52.6} \\
\hline 4 & 4 & 0 & 16.5 & 10.2 & 4 & 1 & $1)$ & & \\
\hline 3 & 5 & $0)$ & 18.5 & 201 & 2 & 4 & 1 & 24.6 & 28.0 \\
\hline 0 & 6 & $0\}$ & 18.3 & 20.1 & 4 & 2 & 1 & - & 14.7 \\
\hline 1 & 6 & 0 & 18.9 & 24.5 & 0 & 5 & 1 & - & 23.2 \\
\hline 5 & 3 & $0\}$ & \multirow{3}{*}{19.7} & 24.0 & 1 & 5 & 1) & \multirow{2}{*}{44.3} & \multirow{2}{*}{27.7} \\
\hline 2 & 6 & $0\}$ & & 24.3 & 3 & 4 & $1\}$ & & \\
\hline 6 & 0 & $0\}$ & & 24.5 & 4 & 3 & 1 & 37.0 & 29.4 \\
\hline 6 & 1 & 0 & - & 8.1 & 5 & 0 & 1 & 26.5 & 12.4 \\
\hline 4 & 5 & $0)$ & & & 2 & 5 & 1) & 16.6 & 18.4 \\
\hline $\begin{array}{l}5 \\
6\end{array}$ & $\begin{array}{l}4 \\
2\end{array}$ & $\left.\begin{array}{l}0 \\
0\end{array}\right\}$ & 26.2 & 37.9 & 5 & 1 & $1\}$ & 10.0 & \\
\hline 3 & 6 & 0 & - & 18 & 5 & 2 & 1 & - & 7.4 \\
\hline 1 & 7 & 0 & - & 4.8 & 4 & 4 & $1)$ & 419 & 358 \\
\hline 6 & 3 & $0\}$ & - & 15.3 & $\begin{array}{l}3 \\
0\end{array}$ & $\begin{array}{l}5 \\
6\end{array}$ & $\left.\begin{array}{l}1 \\
1\end{array}\right\}$ & 41.9 & 35.8 \\
\hline 2 & 7 & $0)$ & & & 1 & 6 & 1 & - & 11.6 \\
\hline 5 & 5 & 0. & 15.1 & 22.2 & 5 & 3 & 1 & - & 3.4 \\
\hline 4 & 6 & 0) & & & 2 & 6 & $1)$ & & \\
\hline 6 & 4 & 0 & - & 3.5 & 6 & 0 & $1\}$ & 22.8 & 25.8 \\
\hline 7 & 1 & 0 & - & 16.4 & 6 & 1 & 1) & & \\
\hline 3 & 7 & $0\}$ & 20.0 & 19.2 & $\begin{array}{l}4 \\
5\end{array}$ & 5 & $\left.\begin{array}{l}1 \\
1\end{array}\right\}$ & 23.3 & 17.2 \\
\hline $\begin{array}{l}7 \\
0\end{array}$ & $\begin{array}{l}2 \\
8\end{array}$ & $0\}$ & - & 1.7 & $\begin{array}{l}5 \\
6\end{array}$ & $\begin{array}{l}4 \\
2\end{array}$ & $\begin{array}{l}1) \\
1\end{array}$ & - & 12.6 \\
\hline $\begin{array}{l}0 \\
5\end{array}$ & $\begin{array}{l}8 \\
6\end{array}$ & 0 & & & 3 & 6 & 1 & - & 5.8 \\
\hline $\begin{array}{l}3 \\
1\end{array}$ & $\begin{array}{l}0 \\
8\end{array}$ & 0 & - & 6.5 & 0 & 7 & 1 & - & 5.7 \\
\hline 7 & 3 & $0\}$ & & & 1 & 7 & $1\}$ & 17.3 & 15.7 \\
\hline 6 & 5 & $0\}$ & - & 87 & $\begin{array}{l}6 \\
2\end{array}$ & $\begin{array}{l}3 \\
7\end{array}$ & 1) & & \\
\hline 4 & 7 & $0\}$ & - & & 5 & 5 & $1\}$ & 27.3 & 18.9 \\
\hline 2 & 8 & 0 & - & 13.5 & 4 & 6 & 1) & & \\
\hline 7 & 4 & 0 & 15.6 & 2.6 & 1 & 1 & 2 & 32.1 & 42.9 \\
\hline 8 & 0 & $0)$ & 165 & 199 & 0 & 2 & 2) & 24.2 & 26.6 \\
\hline $\begin{array}{l}3 \\
8\end{array}$ & $\begin{array}{l}8 \\
1\end{array}$ & $\begin{array}{l}0 \\
0\end{array}$ & 10.5 & 19.9 & $\begin{array}{l}2 \\
1\end{array}$ & $\begin{array}{l}0 \\
2\end{array}$ & $\begin{array}{l}\text { 2) } \\
\text { 2) }\end{array}$ & & \\
\hline 6 & 6 & 0 & & & 2 & 1 & $2\}$ & 50.3 & 58.7 \\
\hline $\begin{array}{l}5 \\
8\end{array}$ & $\begin{array}{l}7 \\
2\end{array}$ & $\begin{array}{l}0 \\
0\end{array}$ & - & 12.0 & 2 & 2 & $2\}$ & 18.4 & 15.6 \\
\hline $\begin{array}{l}7 \\
1\end{array}$ & $\begin{array}{l}5 \\
9\end{array}$ & $\left.\begin{array}{l}0 \\
0\end{array}\right\}$ & 18.7 & 13.7 & $\begin{array}{l}1 \\
3\end{array}$ & $\begin{array}{l}3 \\
0\end{array}$ & $\begin{array}{l}2\} \\
2\}\end{array}$ & 58.9 & 47.3 \\
\hline
\end{tabular}


Crystal Structure of Poly( $\beta$-ethyl- $\beta$-propiolactone)

Table III. (Continued)

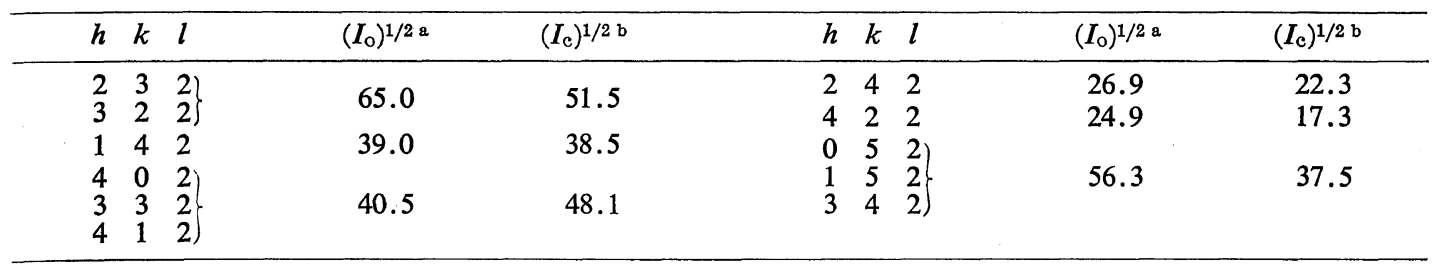

a The observed structure factors $\left(I_{0}\right)^{1 / 2}$ 's were put on the same scale as the $\left(I_{\mathrm{c}}\right)^{1 / 2}$ 's by setting $\sum k\left(I_{\circ}\right)^{1 / 2}=\sum\left(m F_{\mathrm{c}}\right)^{1 / 2}$, where $k$ is the scale factor and $m$ is the multiplicity.

${ }^{b}\left(I_{0}\right)^{1 / 2}$ 's of the reflections which overlap on the X-ray fiber photograph are $\left[\Sigma\left(m F_{\mathrm{c}^{2}}\right)\right]^{1 / 2}$.

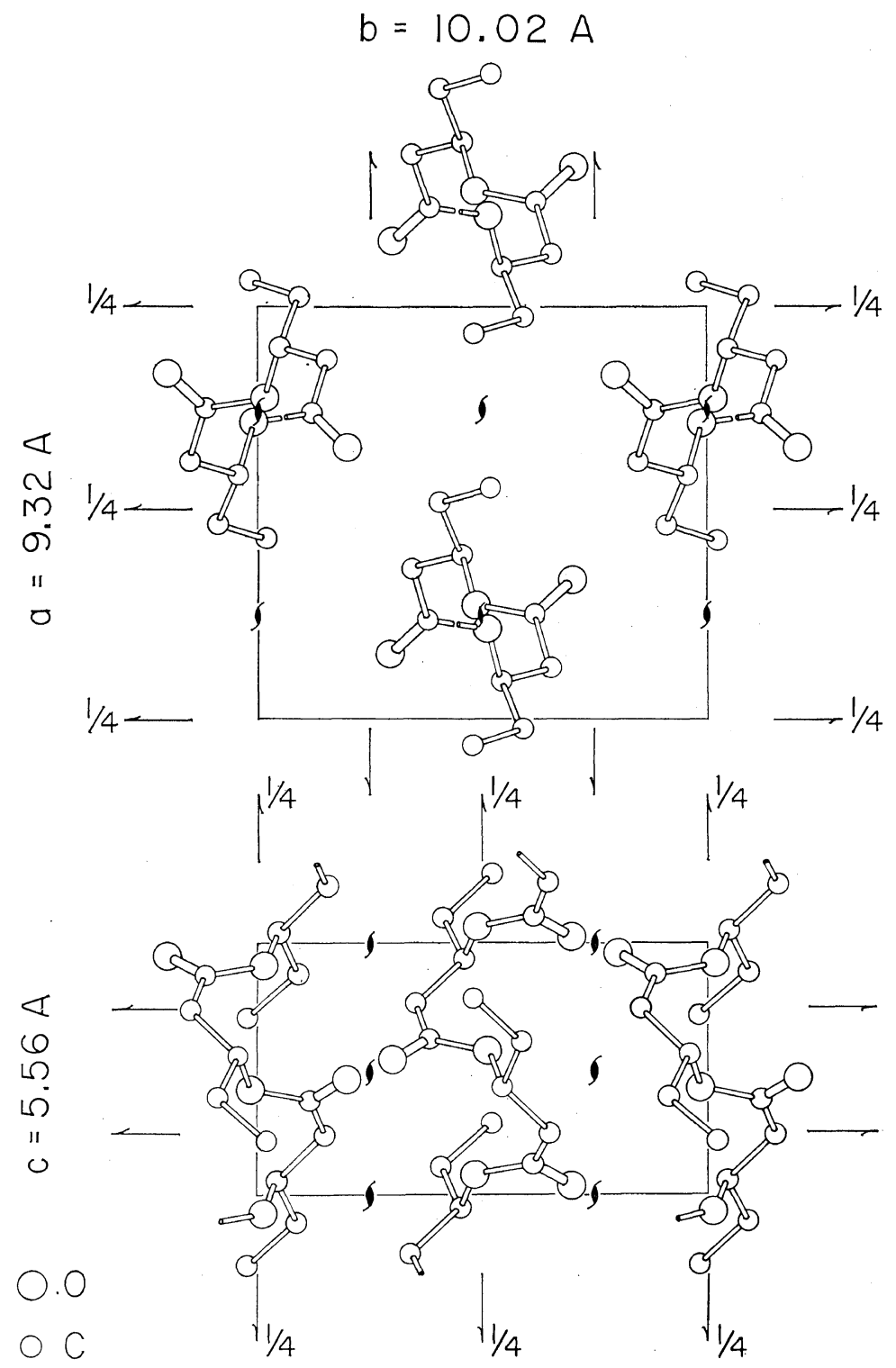

Figure 4. Crystal structure of the rectus polymer chains of poly( $\beta$-ethyl- $\beta$-propiolactone). 
isotactic, and the polymer chain is a left-handed helix if the configuration of the $\beta$-carbon atom is rectus. Accordingly, the sinister polymer should be right-handed. In the crystal, the oxygen atoms of the carbonyl groups are located nearly at the same levels, $z=0$ and $1 / 2$. No absurd intermolecular distances are found and the packing of the molecules is reasonable.

In Figure 5 are shown the molecular dimen-

Poly( $\beta$-propiolacton $)^{* 9}$ modification II

Polypivalolactone ${ }^{4}$

Poly( $\beta$-hydroxybutyrate $)^{1}$

Poly( $\beta$-ethyl- $\beta$-propiolactone)

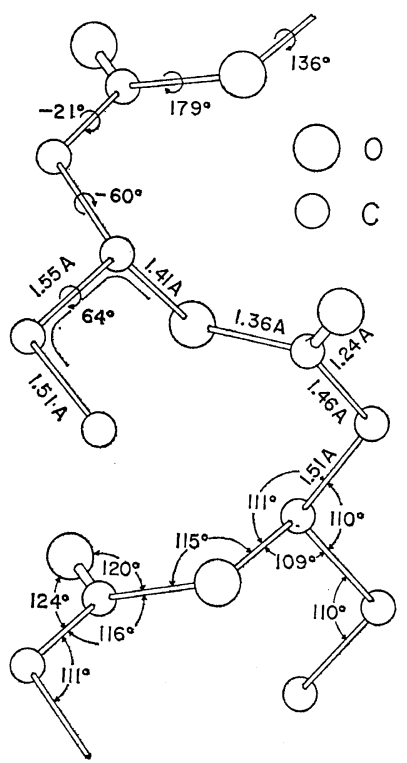

Figure 5. Molecular dimensions of the rectus polymer.

\footnotetext{
* There is another modification of this polymer, the crystal structure of which has not yet been determined.
}

sions of poly ( $\beta$-ethyl- $\beta$-propiolactone) determined by $\mathrm{X}$-ray diffraction in the present study, which is in the case of a left-handed helix of the rectus polymer. The bond lengths and the bond angles are reasonable. The molecular conformation is approximately $(\bar{G} C T S)_{2}$. Here are summarized the skeletal conformations of the polyesters analysed so far, which have the same main chain in terms of chemical structure:

$$
\begin{aligned}
& \begin{array}{c}
-\mathrm{CH}_{2}-\mathrm{CH}_{2}-\mathrm{CO}-\mathrm{O}- \\
T_{T}-T
\end{array}
\end{aligned}
$$

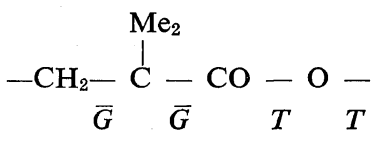

$$
\begin{aligned}
& -41^{\circ}-61^{\circ}-164^{\circ} 178^{\circ} \\
& \mathrm{Me} \\
& \begin{array}{cccc}
\stackrel{\mathrm{Me}}{\mathrm{CH}}-\mathrm{CH}_{2}-\mathrm{CO}-\mathrm{O}- \\
\bar{G} & \bar{G} & T & T \\
-52^{\circ} & -42^{\circ} & -175^{\circ} & 162^{\circ}
\end{array}
\end{aligned}
$$

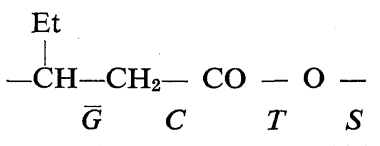

$$
\begin{aligned}
& -60^{\circ}-21^{\circ} 179^{\circ} 136^{\circ}
\end{aligned}
$$

The $\mathrm{C}-\mathrm{C}(\mathrm{O})$ and $\mathrm{O}-\mathrm{C}$ bonds of the polyesters with no side chains analysed so far all have the trans form, except for the skew form of the O-C bonds in the cases of poly(ethylene adipate) and poly(ethylene suberate). ${ }^{10}$ In the present study, the skew form of the $\mathrm{O}-\mathrm{C}$ bond was also found in the case of $\operatorname{poly}(\beta$-ethyl- $\beta$-propiolactone). As for the derivatives of poly( $\beta$-propiolactone), because of the introduction of the substituent group, the $\mathrm{C}-\mathrm{C}(\mathrm{O})$ bond comes to take the gauche form, and, later, the cis form. Thus, it is conceivable that the conformation of the $\mathrm{C}-\mathrm{C}(\mathrm{O})$ bond of polyester is more liable to be affected by the introduction of more bulky substituent groups.

By the energy calculation, seven energetically stable molecular models were found, of which model $I$ is the most stable. And the molecular structure obtained from the X-ray analysis is found to be nearly the same as in model $I$. This again verifies the utility of the energy calculation for selecting molecular models.

Acknowledgment. The authors are grateful to Dr. T. Araki, Dr. K. Teranishi, and Mr. M. Iida for carrying out the synthesis of racemic 
Crystal Structure of Poly( $\beta$-ethyl- $\beta$-propiolactone)

$\operatorname{poly}(\beta$-ethyl- $\beta$-propiolactone $)$.

\section{REFERENCES}

1. M. Yokouchi, Y. Chatani, H. Tadokoro, K. Teranishi, and H. Tani, Polymer, 14, 267 (1973).

2. K. Teranishi, M. Iida, T. Araki, S. Yamashita, and H. Tani, Macromolecules, in press.

3. For example, H. Tadokoro, K. Tai, M. Yokoyama, and M. Kobayashi, J. Polym. Sci. Poly. Phys., 11, 841 (1973).

4. G. Perego, A. Melis, and M. Cesari, Makromol. Chem., 157, 269 (1972).
5. M. Yokouchi, H. Tadokoro, and Y. Chatani, Macromolecules, to be published.

6. S. Arnott and A. J. Wonacott, Polymer, 7, 157 (1966).

7. Y. Takahashi, T. Satō, and H. Tadokoro, $J$. Polym. Sci. Poly. Phys., 11, 233 (1973).

8. H. Sakakihara, Y. Takahashi, H. Tadokoro, N. Oguni, and H. Tani, Macromolecules, 6, 205 (1973).

9. K. Suehiro, Y. Chatani, and H. Tadokoro, Polymer J., to be published.

10. A. Turner-Jones and C. W. Bunn, Acta Cryst., 15, 105 (1962). 